\title{
PRIORITY SCALE ANALYSIS TO DETERMINE PERIODIC MAINTENANCE OF ROADS USING ANALYTICAL HIERARCHY PROCESS IN TULUNGAGUNG DISTRICT
}

\author{
Azis Subandiyah*, Sulistiono Agus \\ Civil Engineering Majoring Construction Management, National Institute of Technology, \\ Malang, Indonesia \\ *E-mail: cup.subandiyah@ymail.com \\ ORCID: 0000-0002-4829-8251
}

\begin{abstract}
Local governments are required to optimize the limited budget. The road, as one of the infrastructures supporting the economy, requires the right allocation of funds. The community proposal through development planning consultations and proposals is a means that has been carried out by the Government of Tulungagung District in allocating road maintenance funds by considering technical and non-technical aspects even though they are not yet optimal and measurable. This research was conducted to obtain the weight of the aspects and criteria, obtain the ranking order of alternative road sections in Tulungagung District which need maintenance, and obtain priority in determining the road sections that will get maintenance according to the highest available budget. The data analysis method applies Analytic Hierarchy Process (AHP) which is used to process answers from the questionnaires distributed to 25 respondents who know and are involved in the allocation of road maintenance funds in Tulungagung District. Based on the research findings and data analysis, it obtains the order of aspects as a priority consideration of maintenance of road sections which includes regional development aspect (A), cost aspect (D), accessibility aspect $(B)$, and technical aspect $(C)$ which have their weights respectively $0.394,0.344$, 0.179 and 0.083 . In addition, the weight of $\mathrm{A} 1 \mathrm{~A} 2, \mathrm{~A} 3, \mathrm{~A} 4, \mathrm{~A} 5, \mathrm{~B} 1, \mathrm{~B} 2, \mathrm{~B} 3, \mathrm{~B} 4, \mathrm{C} 1, \mathrm{C} 2, \mathrm{C} 3$, C4, D1, D2, D3, and D4 criteria have weights of $0.311,0.166,0.087,0.159,0.277,0.401$, $0.297,0.160,0.141,0.427,0.158,0.091,0.324,0.379,0.125,0.244$, and 0.251 respectively. Moreover, the order of alternative road sections in Tulungagung District which need to be maintained is Tamanan-Boyolangu (E4) with weight of 0.313 , Cuwiri-Karangrejo (E2) with weight of 0.227, Boyolangu-Campudarat (E5) with weight of 0.198 , Campudarat-Sodo (E6) with weight of 0.131 , Karangrejo-Sendang (E3) with weight of 0.086, and Cuwiri-Pagerwojo (E1) with weight of 0.045 . In addition, the priority order of roads that will be maintained according to the highest available budget is Tamanan-Boyolangu (E4), Cuwiri-Karangrejo (E2), Boyolangu-Campudarat (E5), and Campudarat-Sodo (E6). Further research can be developed by using other application programs, such as web-based applications, so that it can be accessed from anywhere and can be processed quickly.
\end{abstract}

\section{KEY WORDS}

Priority, periodic maintenance, roads.

The road, as part of infrastructure, has an important role in the national transportation system because it serves $92 \%$ of land transportation for passengers and $90 \%$ of land transportation for goods on the existing road network. In addition, the strategic benefits of the road include creating large-scale employment, increasing domestic resources, and improving the real sector by creating a multiplier effect on national and regional economies.

Road construction is something that is needed as a major support in economic activities both in urban and rural areas and the development of other strategic areas. With the increase in economic growth and the development of traffic, the type and tonnage of vehicles, and government policies in the field of land transportation, the need for road facilities and infrastructure has also increased so that development in the road infrastructure sector must be able to support these conditions, (Glendon and Litherland, 2001). 
The construction of road infrastructure must always pay attention to good quality so that the vehicle users passing through the road feel safe and comfortable. However, road characteristics are always experiencing a decrease in quality, so to maintain the quality of the road, to keep it good or at least reduce quality degradation, routine and periodic maintenance needs to be carried out, (Banerjee et. al., 2012).

In its implementation, to achieve the goal of effective and efficient road maintenance, boundaries must be determined which includes the amount of budget/costs needed/allocated, schedule/time, location of activities, and quality/performance to be achieved. However, in reality, budget/cost constraints become a major factor in carrying out road maintenance activities, (Huang et. al., 2009). Funds are the most important part of the success of a construction project, in which without the right funds it is impossible for the project to be implemented properly. As in other regions, the allocation of funds devoted to the construction projects in Tulungagung District is uncertain and is still very minimal every year.

The biggest challenge in the problem of infrastructure in Tulungagung District is that it requires a large budget but the available funds are very minimal. In 2017, the availability of funds in the management of road infrastructure development amounted to only 111 billion rupiah, which was divided into 4 programs, namely Road and Bridge Development Program, Drainage/Sewer Channel Development Program, Gabion Development Program, and Rehabilitation Program/Maintenance of Roads and Bridges. Meanwhile, the budget allocation for the Road and Bridge Rehabilitation/Maintenance Program is only around $25 \%$ of the total available budget. Thus, there are only around 27 billion rupiahs that can be ascertained. Therefore, it can be seen that the road to be handled is not balanced with the funds available for road maintenance activities. Therefore, it is necessary to prioritize the selection/determination of roads that will be carried out prior maintenance. This election certainly requires the right criteria and methods so that the policies taken can be accounted for.

Selection of alternatives that use several criteria can be performed by a variety of methods including the Dominance method, Feasible Ranges, Lexicography, Effectiveness Index or Analytical Hierarchy Process, (Handfield et. al., 2002). Each method has its own strengths and weaknesses. Therefore, taking which method will be applied should be matched with the problem at hand.

All this time, the determination of the priority sequence for road maintenance in Tulungagung District was based on the community's proposal through the Development Planning Consultation (Musrenbang) mechanism with Development Planning Agency at SubNational Level (BAPPEDA) or through direct proposals from each region starting from the Village to the District level to the Regent and related technical services; in this case, the Department of Public Works Bina Marga, Housing, and Cipta Karya of Tulungagung District with the criteria for budget and technical road. However, the criteria that affect the order of priority have not been based on any method that can be accounted for scientifically, so that the problem of the priority sequence of road maintenance is always a polemic.

The polemic is generally focused on which alternatives should be chosen, considering that many stakeholders will choose an alternative and not what aspects and criteria determine the choice of an alternative. It needs to be realized that aspects and criteria that are in accordance with the wishes of stakeholders have no the same weight. Furthermore, after determining the weight of aspects and criteria, the polling process that needs to be present in the alternative selection process is an inter-alternative assessment process from all stakeholders on the considered aspects and criteria.

The selection of alternatives is carried out on the road that is the authority of the Government of Tulungagung District (District Road) according to the East Java Governor Decree No. 188/139/SK/014/1998 concerning the determination of the status of road sections as district roads in East Java Province. This alternative selection category is emphasized on roads that function as strategic routes connecting sub-districts, agricultural centers, markets and tourist attractions. The road segments included the Cuwiri-Pagerwojo Road Section, Cuwiri-Karangrejo Road Section, Karangrejo-Sendang Road Section, 
Tamanan-Boyolangu Road Section, Boyolangu-Campurdarat Road Section, and Campurdarat-Sodo Road Section.

\section{THEORETICAL FRAMEWORK}

In a project construction, the total cost of the project consists of two types of costs, which relate to the time of project implementation, namely direct costs and indirect costs. Direct costs are costs intended for everything that will become a permanent component of the final project outcome, (Josephson and Hammarlund, 1999). Meanwhile, indirect costs are costs for everything that is not a permanent component of the final project results, but is needed in the framework of the project development process.

The definitions of the road according to Law No.38 of 2004 include:

- Roads are land transportation infrastructure that includes all parts of the road, including complementary buildings and equipment that are intended for traffic, which is on the surface of the ground, above ground level, below ground level, and or water, and above the water surface, except railroad tracks, lorry roads and cable roads.

- The road as one of the transportation infrastructure is an important element in the development of national and state life, fostering the unity and integrity of the nation, the territory of the state, and the function of society and in advancing public welfare as referred to in the Preamble of the 1945 Constitution of the Republic of Indonesia.

- The road as part of the national transportation system has an important role, especially in supporting the economic, social and cultural and environmental fields and is developed through regional development approaches in order to achieve equilibrium and equitable development among regions, establish and strengthen national unity to strengthen national defense and security, and build structures space in order to realize national development goals. To fulfill the role of the road as it should be, the government has the right and obligation to run the road management and so that it can be carried out efficiently and successfully which requires community involvement.

Road construction projects in various regions continue to be developed. In its implementation, it must go through planning that is adjusted to the level of development of road transportation in the area, especially the suitability between the load and traffic density of the vehicle with the capacity of the road carrying capacity, the road network in the center of growth, the production center, and which connects the production center with the marketing regions, (Mahamid, 2011).

Road construction is a construction that is made in such a way in which it can carry the burden of traffic (vehicles) passing over it without undergoing structural changes to the road surface, (Kaliba, 2009). With the development of land transportation, especially motorized vehicles which include the type of size and number, the problem of the smooth flow of traffic, security, comfort and carrying capacity of road pavement must be a concern. The road is a land transportation infrastructure that connects between two or more locations. The road consists of several parts with certain objectives and functions that are formed in a construction. Road construction generally consists of different layers of material, according to the nature used. Broadly speaking, there are three types of pavement construction, namely flexible, rigid, and composite pavement.

In accordance with its characteristics, the road will always tend to experience a decrease in conditions indicated by the occurrence of damage to the pavement. Therefore, to slow down the rate of decrease in conditions and maintain conditions at a reasonable level, the road network needs to be managed properly so that the road can still function at all times. Road maintenance is an effort or action to extend/maintain road service age (timeline) by optimizing limited funds and empowering adequate human resources, materials and equipment so that the road can function properly.

Routine maintenance is carried out since the opening of a road section that has been completed for traffic, carried out continuously throughout the year, found a level of minor damage, carried out to restore the strength, comfort, safety and protection of the road from 
water seepage, carried out in accordance with the conditions field with limited damage area coverage/several places, type of repair work starting from subgrade to surface layer, channel cleaning, roadside maintenance and street space.

Periodic maintenance is carried out periodically with mild to moderate damage which is a maintenance work performed on structural damage, where the pavement conditions on the road surface appear to show symptoms of mild damage (wear out) to moderate damage in the form of then loose of aggregate granules evenly, smooth cracks, rough cracks, wavy surfaces (curly) and bleeding in a wide area of damage coverage. Periodic maintenance activities are carried out to maintain the strength of the road structure, level of safety and comfort, road surface tightness and smooth flow of water so that it does not affect the strength of the subgrade structure and the main road, this activity is carried out periodically, so that the maintenance work is called Periodic Maintenance work.

What is meant by population is a collection of all individuals with a predetermined quality in which the quality or characteristics are called variables. What is meant by a sample is a collection of sampling units that are taken and are sub-populations (Sugiono, 2006).

In order to get an objective priority weight, opinions from the concerned parties were obtained for each criterion. These opinions are collected through a questionnaire filled by respondents with several criteria of answer (Sugiyono, 2006).

Selection of alternatives is often found in all fields of life and decision making to choose which alternative is best is often a problem, especially for alternatives that have many things to consider. Some alternative selection methods that have been developed include the Dominance method, the Feasible Ranges method, the Lexicography method, the Effectiveness Index, Bayes method, Exponential comparison method, Delphi method (Marimin, 2004), and Analytical Hierarchy Process (AHP)

Basically, alternative selection methods with many criteria, such as Effectiveness Index, Comparative Index, MPE, AHP, and others, are applied by giving a score on each criterion for each alternative, in which this score is the result of multiplication the weight of each criteria and performance appraisal of each alternative in each of the criteria concerned. However, the AHP method has advantages compared to other methods, namely in determining the weight of each criterion carried out more objectively than the other methods, namely by using pairwise comparisons. In addition, it is also in the performance evaluation of each alternative, namely in quantifying qualitative matters. Regarding that road maintenance issues involve many interested parties who all need to be treated fairly and transparentlythen for this problem - the research was carried out using AHP.

This AHP method has been tried to be applied by Utomo et al. (2004) to make a decision in the selection of airport development sites in Banyuwangi District with four alternatives, based on criteria in the aspect of flight safety, technical aspects, economic aspects, and environmental aspects. The research makes a sequence of these aspects based on opinions from relevant parties and obtains the safety aspects of flight operations as the most important aspect among others. Meanwhile, economic aspects occupy the third order aspect.

AHP is used to examine problems that begin by defining the problem carefully then compile it into a hierarchy that consists of several levels, i.e. the level of objectives, criteria and alternatives. After arranging the hierarchy, the next is to give a numerical value on subjective considerations about the level of preference at each level of the hierarchy. The final result of AHP is the priority for the existing alternatives aiming to meet the objectives of the problem at hand (Saaty, 1993).

The working principle of AHP (Marimin, 2004) is a simplification of a complex problem that is not structured, strategic, and dynamic into several parts which are then arranged in a hierarchy. Then, the level of importance of each variable is given a subjective numerical value about the relative importance of the variable compared to other variables. From these various considerations, they are then synthesized to determine variables that have high priority and play a role to influence the results of the system. Graphically, AHP decision issues can be constructed as multilevel diagrams, starting with goals, then first level, criteria and finally alternative aspects. 
Some of the advantages obtained in solving problems and making decisions using AHP are (Marimin, 2004):

- Complexity: AHP combines deductive steps and system-based steps in solving complex problems.

- Dependence: AHP can handle the interdependence of elements in a system and does not impose linear thinking.

- Hierarchy Arrangement: AHP reflects the natural tendency of the mind to sort out the elements of a system at different levels and classify similar elements in each level.

- Consistency: AHP tracks the logical consistency of considerations that are used to set priorities.

- Assessment \& Consensus: AHP does not impose consensus by synthesizes a representative result from a variety of different assessments.

- Process Repetition: AHP allows organizations to refine their definition on a problem and improve their judgment and understanding through repetition.

\section{METHODS OF RESEARCH}

Definition of Research. Research is a scientific way to solve a problem and to penetrate the limits of human ignorance. Research activities are carried out by collecting and processing the existing facts so that they can be communicated by the researcher and the findings can be enjoyed and used for the benefit of humans. Based on the method, this research includes the type descriptive research which is to get the aspect weight, criteria weight, and alternatives considered in determining alternatives for road maintenance in Tulungagung District.

The findings of this study are expected to be used as a reference in determining aspects and criteria considered in determining the alternatives of road maintenance in Tulungagung District. This research applied survey method by collecting opinions, experiences and attitudes of respondents to find out the problems that have been experienced in determining the alternatives of road maintenance in Tulungagung District, by taking primary data through a questionnaire. Based on the aspects and criteria that are prioritized in handling the road maintenance in Tulungagung District, the aspects, criteria, and alternatives will be determined to be used as points of the questions to be measured in the form of questionnaires. Furthermore, the results of the questionnaire will be processed by using the Expert Choice 21 tool.

Research Setting. The research setting is road maintenance projects in Tulungagung District which serve as a strategic pathway that connects between sub-districts, agricultural centers, markets, and tourist attractions that are planned to be built in the fiscal year of 2017, such as:

- Cuwiri - Pagerwojo Road Section;

- Cuwiri - Karangrejo Road Section;

- Karangrejo - Sendang Road Section;

- Tamanan - Boyolangu Road Section;

- Boyolangu - Campurdarat Road Section;

- Campurdarat - Sodo Road Section.

Research Aspects and Criteria:

- Regional Development Aspect: Economic Activities (A1), Geographical Setting (A2), Tourist Attractions (A3), Natural Resource Results (A4), Access Expansion to Public Services (A6);

- Accessibility Aspect: Population Number and Distribution (B1), Characteristics and Distribution of the Land Use (B2), Functional Classification of the Road Network (B3), Average Travel Time of the Vehicles (B4);

- Technical Aspect: Traffic Density Level (LHR) (C1), Road Damage Level (C2), Tonnage Load Level of the Vehicles (C3), Road Function (C4); 
- Cost Aspect: The Amount of Material Cost (E1), The Amount of Equipment Cost (E2), The Amount of Transportation Cost (E3), The Amount of Labor Cost (E4).

Data Collection. The data collection was carried out through questionnaires containing statement items relating to the assessment of each aspect and criteria and alternatives using a pairwise comparison of 9-1-9 in which number 1 is the respondent's response code stating that the two elements are equally important, while number 9 is the respondent's response code stating that an element is absolutely more important than other elements.

Data Processing and Analysis. The data obtained from the results of the survey (questionnaire) will be processed to obtain information in the form of tables. The processed data results are used to answer questions in the research problems. The data processing should pay attention to the type of the data collected by concentrating on the objectives to be achieved.

The accuracy in the analysis technique greatly influences the accuracy of the findings of the research. The data analysis technique applied is the AHP method using Expert Choice 21.

\section{RESULTS AND DISCUSSION}

General Description of the Research. This research data were obtained from the results of questionnaires distributed to 25 respondents. After that, it was continued with an analysis to find aspects and criteria that were prioritized for handling in the road maintenance projects requiring the allocation of funds in the Department of Public Works Bina Marga, Housing, and Cipta Karya of Tulungagung District. Next, the Aspects, Criteria and, Alternatives, will be determined as the points of the question to be measured in the form of a questionnaire. Furthermore, questionnaire results will be analyzed to get the weights of aspects, criteria and alternatives.

Determination of the Overall Priority Alternatives. The determination of the overall priority alternatives is the final conclusion of some of the main priorities obtained based on the aspects and criteria. The weighting results for the overall local and global priorities are presented in the following Table 1:

Table 1 - The Overall Local and Global Priorities and Priority Alternatives

\begin{tabular}{|l|l|}
\hline Alternatives & Weights \\
\hline Cuwiri-Pagerwojo (E1) & 0.045 \\
\hline Cuwiri-Karangrejo (E2) & 0.227 \\
\hline Karangrejo-Sendang (E3) & 0.086 \\
\hline Tamanan-Boyolangu (E4) & 0.313 \\
\hline Boyolangu-Campudarat (E5) & 0.198 \\
\hline Campudarat-Sodo (E6) & 0.131 \\
\hline
\end{tabular}

Source: Analysis, 2017.

Based on Table 4.1, it can be seen that overall, the Cuwiri-Pagerwojo (E1) alternative road has a total weight of 0.045 , Cuwiri-Karangrejo (E2) alternative road has a total weight of 0.227 , Karangrejo-Sendang (E3) alternative road has a total weight of 0.086 , TamananBoyolangu (E4) alternative road has a total weight of 0.313 , Boyolangu-Campudarat (E5) alternative road has a total weight of 0.198 , and Campudarat-Sodo (E6) alternative road has a total weight of 0.131 .

Determination of Priority Alternatives Based on the Highest Available Budget. Determination of priority allocation of development funds for road sections that will carry out the maintenance based on the highest available budget can be seen in the following Table 2 .

Based on the above table, it can be seen the order of priority alternatives and the required cumulative costs. Thus, only with the available budget of 27 billion rupiahs, the road sections that get full handling are rank 1 to 4 . Meanwhile, the remaining road sections that cannot be handled because of limited funds can be allocated to the Changes to Regional 
Expenditure Budget (PAPBD) of Tulungagung District for the fiscal year of 2017 or the next fiscal year.

Table 2 - Priority Alternatives Based on the Highest Available Budget

\begin{tabular}{|l|l|l|l|}
\hline Rank Number & Alternatives & Costs & Cumulative Costs \\
\hline 1 & Tamanan-Boyolangu & IDR 4,500,000,000 & IDR 4,500,000,000 \\
\hline 2 & Cuwiri-Karangrejo & IDR 5,300,000,000 & IDR 9,800,000,000 \\
\hline 3 & Boyolangu-Campurdarat & IDR 6,500,000,000 & IDR $16,300,000,000$ \\
\hline 4 & Campurdarat-Sodo & IDR 5,500,000,000 & IDR 21,800,000,000 \\
\hline 5 & Karangrejo-Sendang & IDR 11,000,000,000 & IDR 32,800,000,000 \\
\hline 6 & Cuwiri-Pagerwojo & IDR 12,500,000,000 & IDR 45,300,000,000 \\
\hline
\end{tabular}

Source: Analysis, 2017.

\section{CONCLUSION}

From the results of the analysis and discussion in the previous chapter, the following conclusions can be drawn:

The order of the aspect weights used in determining the allocation of road maintenance funds in Tulungagung District are regional development aspect (A), cost aspect (D), accessibility aspect $(B)$, and technical aspect $(C)$ with the weights respectively $0.394,0.344$, 0.179 and 0.083 . In addition, the criteria weights for A1 A2, A3, A4, A5, B1, B2, B3, B4, C1, C2, C3, C4, D1, D2, D3 and D4 respectively are $0.311,0.166,0.087,0.159,0.277,0.401$, $0.297,0.160,0.141,0.427,0.158,0.091,0.324,0.379,0.125,0.244$, and 0.251 .

The order of alternative ranks of road sections in Tulungagung District which needs to be maintained are Tamanan-Boyolangu (E4) with weight of 0.313 , Cuwiri-Karangrejo (E2) with weight of 0.227 , Boyolangu-Campudarat (E5) with weight of 0.198, Campudarat-Sodo (E6) with weight of 0.131 , Karangrejo-Sendang (E3) with weight of 0.086 , and CuwiriPagerwojo (E1) with weight of 0.045 .

The priority for determining the road sections that needs to be adjusted according to the highest available budget is Tamanan-Boyolangu (E4), Cuwiri-Karangrejo (E2), Boyolangu-Campudarat (E5) and Campudarat-Sodo (E6).

\section{SUGGESTIONS}

Based on the results of the analysis in this research, the followings are the suggestions for the related parties (policy makers):

The preparation of plans for allocating road maintenance funds in Tulungagung District needs to be carried out with clear and measurable mechanisms. One of them is using the Analytic Hierarchy Process (AHP) method as described above.

Local governments need to think about mechanisms in determining aspects and criteria. The mechanism can be carried out by conducting socialization through official meetings involving all elements of government and community representatives such as the population used in this research.

It is necessary to hold discussions between the stakeholders in determining proposals from all the criteria proposed by stakeholders. Thus, all the interests in the form of criteria can be accommodated because political factors also determine priorities. For the community, with the clarity of the mechanism as mentioned above, it will make it easier for the public to understand the direction of the development of the local government so that it is expected that there will be no conflict of interest when submitting proposals for handling the road between the concerned parties.

Future research can be carried out by using aspects, criteria and other alternatives to obtain more applicable research results. 


\section{REFERENCES}

1. Banerjee, A., Duflo, E., \& Qian, N. (2012). On the road: Access to transportation infrastructure and economic growth in China(No. w17897). National Bureau of Economic Research.

2. Glendon, A. I., \& Litherland, D. K. (2001). Safety climate factors, group differences and safety behaviour in road construction. Safety science, 39(3), 157-188.

3. Handfield, R., Walton, S. V., Sroufe, R., \& Melnyk, S. A. (2002). Applying environmental criteria to supplier assessment: A study in the application of the Analytical Hierarchy Process. European journal of operational research, 141(1), 70-87.

4. Huang, Y., Bird, R., \& Bell, M. (2009). A comparative study of the emissions by road maintenance works and the disrupted traffic using life cycle assessment and microsimulation. Transportation Research Part D: Transport and Environment, 14(3), 197-204.

5. Josephson, P. E., \& Hammarlund, Y. (1999). The causes and costs of defects in construction: A study of seven building projects. Automation in construction, $8(6), 681-687$.

6. Kaliba, C. (2009). Cost escalation and schedule delays in road construction projects in Zambia. International journal of project management, 27(5), 522-531.

7. Mahamid, I. (2011). Risk matrix for factors affecting time delay in road construction projects: owners' perspective. Engineering, Construction and Architectural Management, 18(6), 609-617.

8. Marimin. (2004), Pengambilan Keputusan Kriteria Majemuk, Grasindo, Jakarta.

9. Saaty, T.L, (1993), Pengambilan Keputusan (Cetakan Ke II), PT. Pustaka Binaman Presindo, Jakarta.

10. Sugiyono. (2006). Statistika untuk Penelitian, Cetakan ke sembilan, CV Alfabeta, Bandung. 